\title{
Pengaruh Monoklonal Antibodi Bovine Zona Pelusida 3 (bZP3) terhadap Diameter dan Atresia Folikel Ovarium Mencit (Mus musculus)
}

\author{
Effect of Bovine Zona Pelusida 3 (bZP3) Monoclonal Antibody on Diameter and Atresia of Mice \\ (Mus musculus) Ovarian Follicles
}

\author{
Annisa Trissatharra', Sri Ratna Dwiningsih', Ratna Sofaria Munir ${ }^{3}$ \\ 'Program Pendidikan Dokter, ${ }^{2}$ Departemen Obstetri dan Ginekologi, \\ ${ }^{3}$ Departemen Farmakologi Kedokteran, Fakultas Kedokteran, Universitas Airlangga \\ RSUD Dr Soetomo, Surabaya
}

\begin{abstract}
ABSTRAK
Tujuan: Untuk mengetahui pengaruh antibodi monoklonal bZP3 dalam folikel ovarium yang mengalami atresia dan diameter berbagai folikel ovarium.

Bahan dan Metode: Penelitian ini merupakan penelitian eksperimental sejati dengan post only control group design. Sampel berupa 36 mencit (Mus musculus) betina yang terbagi menjadi 6 kelompok, 3 kelompok kontrol (kelompok 1, 2, dan 3) diberi Phospatase Buffer Saline (PBS) $50 \mu \mathrm{l}$ dan 3 kelompok perlakuan (kelompok 4, 5, dan 6) diberi Mab bZP3 $50 \mu$ l. Kelompok 1 dan 4 dihentikan pada hari ke-5, kelompok 2 dan 5 dihentikan pada hari ke-10, dan kelompok 3 dan 6 dihentikan pada hari ke-20. Evaluasi folikel atresia ovarium dan diameter folikel ovarium dilakukan dengan hematoxylin eosin (HE) dan data diolah dengan statistik parametrik.

Hasil: Tidak ada perbedaan signifikan pada berbagai aspek folikel atresia dan diameter folikel ( $p>0,05)$, namun secara deskriptif, jumlah folikel yang mengalami atresia pada kelompok perlakuan primer, sekunder, dan tersier lebih tinggi daripada kelompok kontrol, kecuali pada hari ke-20 waktu observasi.

Simpulan: Pemberian Mab bZP3 tidak berpengaruh terhadap jumlah folikel atresia dan diameter folikel selama waktu pengamatan.
\end{abstract}

Kata kunci: Mab bZP3, folikel atresia, diameter folikel

\begin{abstract}
Objectives: To identify the effect of monoclonal antibody bZP3 at ovarian follicles that undergo atresia and diameter of various ovarian follicles.

Materials and Methods: This is a true experimental research with post only control group design. Samples were 36 female mices (Mus musculus) which is divided into 6 groups, there are 3 control groups (group 1, 2, and 3) injected by Phospatase Buffer Saline (PBS) 50 $\mu 1$ and 3 treatment groups (group 4, 5, and 6)

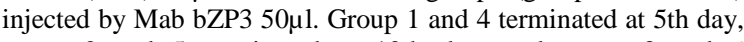
group 2 and 5 terminated at 10th day, and group 3 and 6 terminated at 20th day. Evaluation of atretic ovarian follicles and diameter of ovarian follicles performed by hematoxylin eosin (HE) and the data processed by parametric statistic.

Results: There are no significant in different among groups in the aspect of atretic follicles and diameter of folicles $(p>0.05)$, but descriptively, number of follicles undergo atresia of the follicle primary, secondary, and tertiary treatment group was higher than the control group, except on the 20th day of observation time. Conclusion: administration of Mab bZP3 had no effect to amount of atretic follicles and diameter of folicles during observation time.
\end{abstract}

Keywords: Mab bZP3, atretic follicles, diameter follicles

Correspondence: Annisa Trissatharra, Program Pendidikan Dokter, Fakultas Kedokteran, Universitas Airlangga, Jalan Prof dr Moestopo 47, Surabaya 60131, Indonesia.

\section{PENDAHULUAN}

Awal abad 20 terjadi peningkatan jumlah populasi manusia yang sangat eksponensial sehingga daya dukung kehidupan manusia menjadi sangat terbatas. Untuk itu diperlukan pengendalian laju penambahan penduduk. Kontrasepsi merupakan salah satu cara pengendalian laju penduduk, namun kontrasepsi konvensional yang ada sekarang masih menimbulkan banyak keluhan. Penelitian mengenai kemungkinan penggunaan antibodi untuk kontrasepsi terus dikembangkan dan imunokontrasepsi menunjukkan harapan yang menjanjikan. Salah satu kandidat imunokontrasepsi yang saat ini dikembangkan adalah antibodi anti zona pelusida (ZP) yang merupakan matrik glikoprotein ekstraseluler yang mengelilingi oosit mamalia yang berperan penting dalam menghambat interaksi antara sperma dan ovum. Zona pelusida pada manusia mengandung glikoprotein spesifik yaitu ZP1, $\mathrm{ZP}$, ZP3 dan ZP4, dimana molekul glikoprotein ZP3 berperan sebagai reseptor primer yang bertanggung jawab terhadap menempelnya spermatozoa serta sebagai pencetus reaksi akrosom. ${ }^{1,2}$

Folikel yang hadir dalam berbagai ukuran mewakili tahapan dari folikulogenesis. Diameter folikel merupakan aspek morfologi penting ketika memasuki tahap pertumbuhan, baik karena proliferasi sel granulosa, peningkatan ukuran oosit, maupun sel teka. Ukuran dimater folikel dapat digunakan menentukan keberlangsungan hidup folikel, menjadi folikel dominan yang terus berkembang untuk diovulasikan, atau 
menjadi folikel non dominan melalui proses apoptosis. $^{3,4,5}$

Antibodi zona pelusida akan merusak struktur gap junction yang berada di zona pelusida. Rusaknya perkembangan normal gap junction antara oosit dan sel granulosa dapat mengakibatkan atresia folikel, gangguan maturasi oosit, dan fertilasi. ${ }^{6}$ Rangkaian penelitian terkait potensi imunokontrasepsi ZP3 masih memunculkan perdebatan, untuk itu penelitian me-ngenai potensi imunokontrasepsi dengan glikoprotein ZP dan antibodi ZP masih terus dilakukan untuk menilai keefektifannya, evaluasi keamanan dan potensi rever-sibilitas. ${ }^{2}$

\section{BAHAN DAN METODE}

Penelitian ini adalah True Experiment dengan pendekatan Post Only Control Group Design yang dilakukan di Laboratorium Patologi Veteriner Fakultas Kedokteran Universitas Airlangga dan Laboratorium Parasitologi Fakultas Kedokteran Universitas Bra-wijaya. Sampel dari penelitian menggunakan mencit (Mus musculus) betina sebanyak 36 ekor. Sampel selanjutnya dikelompokkan mejadi 6 (enam) kelompok, yaitu kelompok 1-3 adalah kelompok kontrol yang diberi 50 $\mu 1$ PBS dan kelompok 4-6 adalah kelompok perlakuan yang diberi $50 \mu \mathrm{l}$ Mab bZP3. Selanjutnya dilakukan pembedahan pada hari ke-5 untuk kelompok 1 dan 4 , hari ke-10 untuk kelompok 2 dan 5, serta hari ke-20 untuk kelompok 3 dan 6 . Pengamatan terhadap jumlah folikel ovarium yang mengalami atresia dan diameter folikel ovarium mencit diamati dengan pewarnaan $\mathrm{HE}$.

\section{Prosedur Pemberian PBS dan Mab bZP3}

Sebelum mencit mendapat perlakuan, dilakukan aklimatisasi selama 10 hari. Dilakukan swab vagina untuk menentukan fase estrus pada mencit. Mencit yang teridentifikasi berada pada fase estrus langsung diberikan perlakuan dengan penyuntikan secara intra muskuler (IM) 50 $\mu \mathrm{l}$ PBS pada kelompok kontrol (kelompok 1, 2, dan 3) dan penyuntikan $50 \mu \mathrm{l} \mathrm{Mab}$ bZP3 pada kelompok perlakuan (kelompok 4, 5, dan 6).

\section{Prosedur Pembedahan}

Pembedahan dilakukan pada hari ke 5 (kelompok 1 dan 4), hari ke 10 (kelompok 2 dan 5), dan hari ke 20 (kelompok 3 dan 6). Pembedahan dilakukan untuk mengambil ovarium kiri dan kanan mencit, lalu dibuat menjadi preparat histopatologi dengan dimasukkan dalam larutan PFA $10 \%$ untuk pengecatan HE dan diproses menggunakan metode statistik parametrik.

\section{Pengamatan Jumlah Folikel yang Mengalami Atresia}

Tanda-tanda adanya apoptosis yang terjadi pada sel granulosa dapat dilihat melalui jumlah folikel yang mengalami atresia diamati dengan perbesaran 400x dibawah mikroskop cahaya biasa merk Nikon Eclipse $\mathrm{Ci}$ yang dilengkapi dengan Digital Camera Optilab Plus 12 Megapixel yang telah dikalibrasi, serta dilengkapi dengan software pengolah gambar Image Raster .

\section{Pengamatan Diameter Folikel}

Hasil ukur diameter folikel primer, sekunder dan tersier mencit (Mus musculus) yang diambil dari ovarium mencit yang dipotong melintang kemudian dibuat slide histologi untuk selanjutnya dilakukan pewarnaan $\mathrm{HE}$ dan diukur diameternya menggunakan perbesaran 400x dibawah mikroskop cahaya biasa merk Nikon Eclipse $\mathrm{Ci}$ yang dilengkapi dengan Digital Camera Optilab Plus 12 Megapixel yang telah dikalibrasi, serta dilengkapi dengan software pengolah gambar Image Raster 3 . Pengukuran dilakukan setelah dilakukan kalibrasi terlebih dahulu pada mikroskop sehingga didapatkan hasil yang akurat. Folikel dihitung luasnya hingga mencapai lapisan teka eksterna dengan bantuan software Image Raster 3, untuk mendapatkan diameter dari folikel digunakan rumus luas lingkaran untuk mendapatkan jari-jari (r) folikel. Nilai $r$ yang telah didapatkan dimasukkan ke dalam rumus $\mathrm{D}=2 \mathrm{x} \quad \mathrm{r}$ untuk mendapatkan diameter folikel.

\section{HASIL DAN PEMBAHASAN}

Diamati jumlah folikel ovarium yang mengalami atresia dan diameter berbagai macam folikel ovarium pada Gambar 1. Foto 1 adalah folikel primordial yang memiliki satu lapis sel pipih yang mengelilingi oosit (panah putih), folikel primer dengan satu lapis sel kubus yang mengelilingi oosit (panah jingga), dan folikel sekunder normal dengan lebih dari satu lapis sel granulosa (panah hijau). Foto 2 adalah folikel primer atretik yang mengalami karyoreksis dan piknotis pada selapis kubis sel granulosa. Foto 3 adalah folikel sekunder atretik yang mengalami karyoreksis dan piknotis pada sel granulosa. Foto 4 adalah folikel tersier normal yang telah memiliki antrum folikuli, serta terbentuknya lapisan sel teka interna dan teka eksterna. Foto 5 adalah folikel tersier atretik yang mengalami karyoreksis dan piknotis pada sel granulosa. 


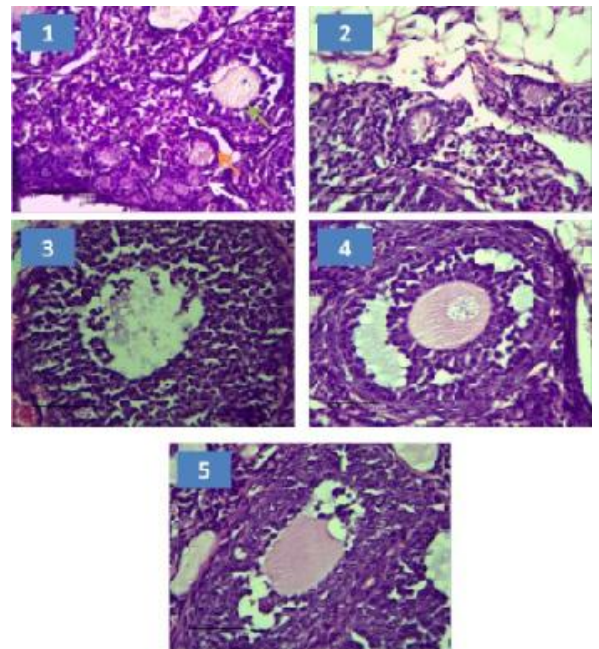

Gambar 1. Folikel ovarium mencit

\section{Hasil Analisa Data Jumlah Folikel Ovarium yang Mengalami Atresia}

Tabel 1. Jumlah folikel ovarium yang mengalami atresia

\begin{tabular}{|c|c|c|c|c|}
\hline \multirow[b]{2}{*}{ Kelompok } & \multirow[b]{2}{*}{ Pengamatan } & \multicolumn{3}{|c|}{ Mean \pm SD } \\
\hline & & $\begin{array}{l}\text { Jumlah Folikel } \\
\text { Primer Atresia }\end{array}$ & $\begin{array}{l}\text { Jumlah Folikel } \\
\text { Sekunder Atresia }\end{array}$ & $\begin{array}{l}\text { Jumlah Folikel } \\
\text { Tersier Atresia }\end{array}$ \\
\hline \multirow[t]{3}{*}{ Kontrol } & Harike-5 & $0.6 \pm 0.89$ & $4.33 \pm 3.5$ & $3.17 \pm 3.06$ \\
\hline & Hari ke-10 & $0.2 \pm 0.45$ & $2.83 \pm 2.79$ & $2.83 \pm 2.56$ \\
\hline & Hari ke-20 & $1 \pm 0.71$ & $9.67 \pm 3.67$ & $4.5 \pm 3.15$ \\
\hline \multirow[t]{3}{*}{ Perlakuan } & Hari ke-5 & $1=1$ & $5.33 \pm 2.94$ & $6.83 \pm 1.47$ \\
\hline & Harike-10 & $0.6 \pm 0.89$ & $4.67 \pm 2.81$ & $5 \pm 0.89$ \\
\hline & Harike-20 & $0.6 \pm 0.55$ & $5.33 \pm 2.25$ & $3 \pm 2.37$ \\
\hline \multicolumn{2}{|c|}{$p$-value } & 0.741 & 0.475 & 0.43 \\
\hline
\end{tabular}

Perbandingan jumlah folikel yang mengalami atresia pada masing-masing kelompok ditampilkan pada histogram berikut:

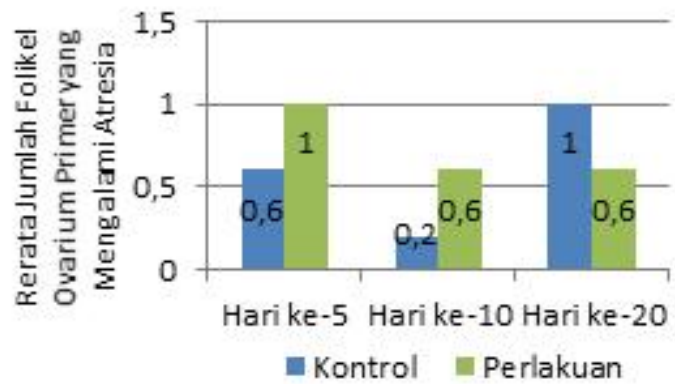

Gambar 2. Rerata jumlah folikel ovarium primer yang mengalami atresia antar waktu pengamatan

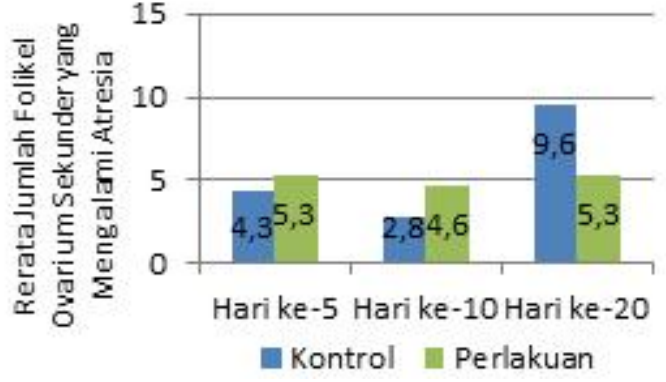

Gambar 3. Histogram rerata jumlah folikel ovarium sekunder yang mengalami atresia antar waktu pengamatan
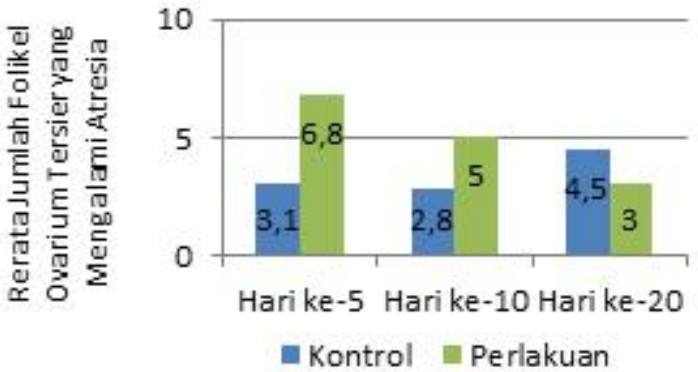

Gambar 4. Histogram rerata jumlah folikel ovarium tersier yang mengalami atresia antar waktu pengamatan

Evaluasi dari tabel 1 dan gambar 2,3, dan 4 menunjukkan hasil pengamatan jumlah folikel yang mengalami atresia pada folikel secara deskriptif dan menunjukkan bahwa rerata jumlah folikel yang mengalami atresia pada folikel primer, sekunder, dan tersier pada kelompok perlakuan lebih tinggi daripada kelompok kontrol, kecuali pada hari ke-20 waktu pengamatan, yaitu rerata jumlah folikel yang mengalami atresia pada folikel primer, sekunder, dan tersier lebih tinggi pada kelompok kontrol dibandingkan dengan kelompok perlakuan. Dengan p-value > 0.05 menunjukkan bahwa data meskipun ada perbedaan namun tidak signifikan.

\section{Hasil Analisa Data Diameter Folikel}

Tabel 2. Diameter folikel ovarium

\begin{tabular}{|c|c|c|c|c|}
\hline & & \multicolumn{3}{|c|}{ Mean I SD } \\
\hline & & Diameter & Diameter Folikel & Diameter \\
\hline Kelnmpok & Pengamatan & Fulikel Primer & Sckunder & Fulikel Tersior \\
\hline \multirow[t]{3}{*}{ Kontrol } & Esrikc-5 & $01:=0+1$ & $016 \pm 0.4$ &, $91 \pm 21 ;$ \\
\hline & Hurike 10 & $0.23=0.02$ & $0.11 \pm 0.06$ & $5.29 \pm 1.32$ \\
\hline & Ilarike-20 & $0.2 \times 0.07$ & $0.55,0.17$ & $4.89 \times 0.37$ \\
\hline \multirow[t]{3}{*}{ Poriakusn } & Esrikc-5 & $0.2-0.09$ & $0.52+0.12$ & $4.45+1.01$ \\
\hline & Harike-10 & $C 17=0.13$ & $046 \pm 005$ & $530 \pm 147$ \\
\hline & Herike 20 & $0.2 s=0.11$ & $0.11 \pm 0.08$ & $3.02 \pm 0.62$ \\
\hline & & $0.2 / 6$ & $0.32 i$ & 0.387 \\
\hline
\end{tabular}


Perbandingan diameter folikel pada masing-masing kelompok ditampilkan pada histogram berikut:

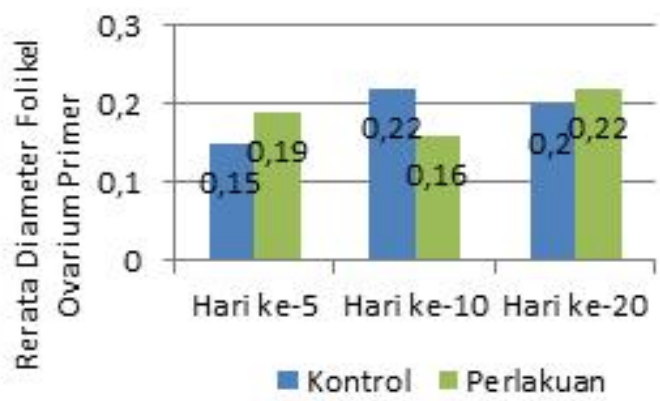

Gambar 5. Histogram rerata diameter folikel ovarium primer antar waktu pengamatan

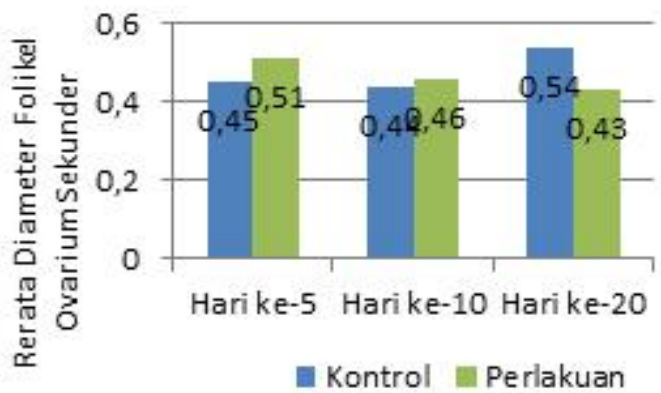

Gambar 6. Histogram Rerata Diameter Folikel Ovarium Sekunder antar Waktu Pengamatan

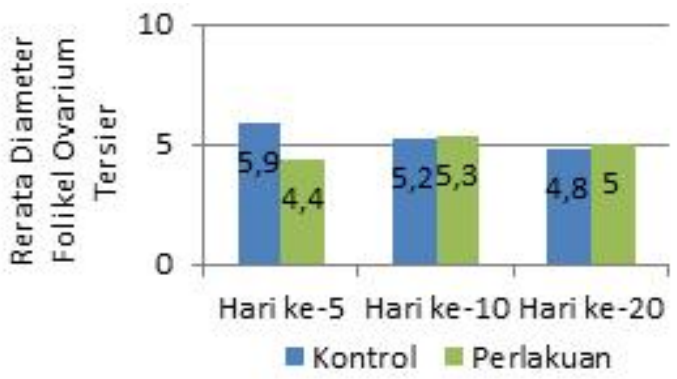

Gambar 7. Histogram Rerata Diameter Folikel Ovarium Tersier antar Waktu Pengamatan

Analisis dari tabel 2 dan gambar 5,6, dan 7 menunjukkan secara deskriptif bahwa tidak didapatkan perbedaan ukuran diameter folikel primer, sekunder, dan tersier pada kelompok kontrol dan perlakuan. Dengan harga $\mathrm{p}$-value $>0.05$ menunjukkan bahwa data meskipun ada perbedaan namun tidak signifikan secara statistik.

Secara deskriptif didapatkan data bahwa rerata jumlah folikel yang mengalami atresia pada folikel primer, sekunder, dan tersier pada kelompok perlakuan lebih tinggi daripada kelompok kontrol, kecuali pada hari ke-
20 waktu pengamatan, yaitu rerata jumlah folikel yang mengalami atresia pada folikel primer, sekunder, dan tersier lebih tinggi pada kelompok kontrol dibandingkan dengan kelompok perlakuan. Dengan harga p-value > 0.05 , menunjukkan bahwa data meskipun ada perbedaan namun tidak signifikan. Hal ini berbeda dengan penelitian lain yang mengatakan bahwa pemberian antibodi ZP2 dan antibodi ZP3 pada kultur folikel mencit akan menyebabkan gangguan pembentukan folikel antral. ${ }^{6}$ Jumlah folikel ovarium primer, sekunder, dan tersier yang mengalami atresia tidak berbeda secara signifikan antara kelompok kontrol dan perlakuan pada penelitian ini kemungkinan disebabkan karena spesifisitas yang tinggi dari antibodi monoklonal bZP3. Hal ini memunculkan anggapan bahwa pemberi-an Mab bZP3 hanya menyebabkan kerusakan lokal pada zona pelusida. Mab bZP3 hanya mengenali bZP3 bukan zona pelusida yang lainnya. ${ }^{2}$ Kerusakan yang hanya terjadi pada zona pelusida seperti disebutkan diatas, diduga hanya mengganggu faktor pertumbuhan folikel yang bekerja secara autokrin dan parakrin. Sedangkan faktor pertumbuhan lain yang bekerja secara endokrin, seperti FSH yang sangat berpengaruh pada proses seleksi kemungkinan tidak mengalami perubahan. Selain itu kerusakan yang ditimbulkan oleh Mab bZP3 kemungkinan bekerja pada oosit atau saat fertilasi, bukan pada pertumbuhan folikel sebagaimana di sampaikan pada penelitian lain yaitu rusaknya perkembangan normal gap junction antara oosit dan sel granulosa dapat mengakibatkan atresia folikel, gangguan maturasi oosit, dan fertilasi. ${ }^{6}$

Diameter folikel dapat dijadikan indikator untuk memprediksi keberlangsungan hidup folikel antara folikel tersebut dapat bertahan hidup hingga dapat diovulasikan atau mengalami atresia. Secara deskriptif tidak banyak perbedaan ukuran diameter folikel primer, sekunder, dan tersier pada kelompok kontrol dan perlakuan. Pada hasil pengujian statistik menunjukkan bahwa tidak ada perbedaan diameter folikel yang signifikan pada kelompok perlakuan dan kontrol (pvalue >0.05). Hal ini menunjukkan bahwa pemberian imunisasi Mab bZP3 tidak memberikan pengaruh terhadap diameter folikel primer, sekunder, dan tersier. Ukuran folikel dipengaruhi oleh proliferasi sel granulosa dan membesarnya ukuran oosit. ${ }^{5}$ Sel-sel lain yang berperan antara lain sel teka interna, sel teka eksterna, cumulus oophorus serta peningkatan cairan rongga folikel juga mempengaruhi ukuran folikel. ${ }^{2}$

Tidak berpengaruhnya imunisasi Mab bZP3 terhadap ukuran diameter ini diduga karena antibodi monoklonal yang dimiliki oleh Mab bZP3 merupakan antibodi jenis monoepitop dimana antibodi ini hanya mengenali dengan satu jenis epitop yang spesifik dan sesuai. Sebagai antibodi yang spesifik, Mab bZP3 yang 
merupakan antibodi monoklonal hanya mempunyai satu macam epitop sehingga hanya dapat mengidentifikasi antigen yang spesifik. ${ }^{7}$ Semakin tinggi spesifisitas antibodi, maka antibodi tersebut hanya bereaksi dengan satu antigen saja. Monoklonal antibodi ini akan langsung berikatan dengan ZP3 (sebagai antigen) dan mempengaruhi fungsinya sebagai reseptor spermatozoa dan induser reaksi akrosom. Begitu juga sel-sel lain pada oosit tidak akan terpengaruh oleh Mab bZP3 ini. Penelitian ini juga bertujuan untuk mengetahui pengaruh pemberian antibodi monoklonal pada berbagai waktu pengamatan terhadap jumlah folikel yang mengalami atresia pada mencit (Mus musculus). Setelah dilakukan injeksi PBS untuk kelompok kontrol dan perlakuan, waktu pengamatan jumlah folikel yang mengalami atresia pada mencit (Mus musculus) dilakukan pada hari ke 5, hari ke 10, dan hari ke 20 sesuai dengan siklus estrus mencit. Dilakukan pembedahan dilakukan pada fase estrus untuk mendapatkan data reproduksi. ${ }^{8}$ Waktu pengamatan itu merujuk pada siklus reproduksi manusia yang dikenal dengan siklus menstruasi yang berlangsung selama kurang lebih 28 hari, sedangkan pada mencit disebut siklus estrus yang berlangsung selama 4-5 hari. Pada intinya, siklus reproduksi yang singkat inilah yang menjadikan mencit sebagai animal model yang ideal untuk meneliti perubahan yang terjadi selama siklus reproduksinya. ${ }^{9}$

Didapatkan pada waktu pengamatan hari ke 5 (1x siklus estrus) dan hari ke 10 (2x siklus estrus), rerata jumlah folikel primer, sekunder, dan tersier yang mengalami atresia pada kelompok perlakuan lebih tinggi daripada kelompok kontrol. Sedangkan pada hari ke 20 (4x siklus estrus), rerata jumlah folikel primer, sekunder, dan tersier yang mengalami atresia pada kelompok perlakuan lebih rendah daripada kelompok kontrol. Pada hasil pengujian statistik menunjukkan bahwa tidak ada perbedaan yang signifikan jumlah folikel yang mengalami atresia pada kelompok perlakuan dan kontrol ( $\mathrm{p}$ value >0.05). Hal ini kemungkinan disebabkan karena pendeknya rentang waktu pengamatan. Perubahan kemungkinan baru terjadi setelah 20 hari, sesuai dengan waktu eliminasi IgG.

Pada penelitian in vivo, penilaian efek dan lama efek suatu bahan atau obat termasuk imunoglobulin (antibodi) sangat bergantung pada farmakodinamik bahan atau obat tersebut. Beberapa kelas imunoglobulin (IgG, IgA, IgM, IgD, maupun IgE) dapat digunakan sebagai imunisasi pasif, tergantung penggunaannya. ${ }^{10}$ Pertimbangan dalam penggunaan imunoglobulin antara lain: 1) waktu paruh intravaskular; 2) kecepatan katabolisme; dan 3) aplikasi spesifik dari kelas imunoglobulin tertentu. IgG tidak dieliminasi lewat urin karena ukuran molekulnya yang besar11. Imunoglobulin G memiliki waktu paruh terpanjang yaitu 21 hari.
Kondisi ini sesuai untuk aktivitas dalam jangka panjang dalam penggunaan sistemik. Pada pemberian antibodi imunitas diperoleh segera setelah suntikan, dan berlangsung selama masa hidup IgG secara in vivo yaitu sekitar 3 minggu. ${ }^{12}$

Pemberian imunokontrasepsi pada berbagai waktu pengamatan diperlukan untuk menilai efektifitas dan keamanannya. Hal ini sesuai bahwa syarat vaksin kontrasepsi adalah harus mempunyai peran spesifik dalam proses reproduksi dan tidak menimbulkan efek samping dalam proses reproduksi. ${ }^{2}$

Mencit kontrol dipaparkan PBS dan mencit perlakuan dipaparkan Mab bZP3 yang selanjutnya diamati untuk mengetahui pengaruh pemberian antibodi monoklonal Mab bZP3 pada berbagai waktu pengamatan terhadap penurunan diameter folikel mencit (Mus musculus). Pengamatan hanya dilakukan sekali karena untuk melakukan pengamatan mencit harus diterminasi, sehingga tiap kelompok hanya bisa dilakukan sekali yaitu hari ke 5 untuk kelompok 1 dan 4, hari ke 10 untuk kelompok 2 dan 5, dan hari ke 20 untuk kelompok 3 dan 6 .

Didapatkan penurunan diameter pada kelompok perlakuan hari ke 10 pada folikel primer, hari ke 20 pada folikel sekunder, dan hari ke 5 pada folikel tersier, sedangkan kelompok lainnya mengalami peningkatan diameter. Dengan harga $\mathrm{p}$-value $>0.05$, menunjukkan bahwa data meskipun ada perbedaan namun tidak signifikan. Hal ni menunjukkan bahwa ada rerata diameter folikel primer, sekunder, dan tersier yang bervariasi pada berbagai waktu pengamatan pada masing-masing kelompok kontrol dan perlakuan.

Diameter folikel dapat menjadi acuan keberlangsungan hidup folikel. Banyak faktor yang mempengaruhi perkembangan folikel yang tidak diteliti dalam penelitian ini yang dapat mempengaruhi diameter folikel. Proses perkembangan folikel ovarium diatur oleh berbagai mekanisme endokrin, parakrin, dan autokrin yang saling berkoordinasi menyeleksi folikel sampai ovulasi. ${ }^{13,14}$ Akan tetapi penelitian lain me-nunjukkan bahwa folikel preantral tikus yang dikultur dengan antibodi anti-ZP3 mengalami pengecilan diameter akibat antibodi anti-ZP3 yang mengganggu perkembangan folikel dan oosit mencit. ${ }^{6}$

\section{SIMPULAN}

Pemberian Mab bZP3 tidak meningkatkan jumlah folikel ovarium yang mengalami atresia dan tidak menurunkan diameter folikel ovarium pada mencit (Mus musculus) pada berbagai waktu pengamatan. 


\section{DAFTAR PUSTAKA}

1. Gupta SK, Bansal P, Ganguly A, Bhandari B dan Chakrabarti K. Human Zona Pellusida Glycoprotein: Functional Relevance During Fertilization. Journal Of Reproductive Immunology. 2009;83:50-5.

2. Sumitro SB, Aulanni'am, Soewarto S, Ciptadi G, Widyarti $S$ dan Kurniawan D. Imunokontrasepsi Konsep-Konsep Dasar Dan Bunga Rampai Penelitian. Surabaya: Pusat Penerbitan Dan Percetakan Unair (AUP); 2011. h. 1-95.

3. Chang RjdE G. Folliculogenesi, Ovulation, and Luteogenesis in Endocrinology. 6th Eds. Saunder Elsevier; 2010.

4. Erickson GF. Follicle Growth and Development, Global Library Women's Med. Follicle Growth and Development. Global Library Women's Med. 2008.

5. Gougeon A. Human Ovarian Follicular Development: From Activation of Resting Follicle to Preovulatory Maturation. Anales d'Endocrinologies. 2010;21:132-43.

6. Colongos G, Hasegawa A, Komori S and Koyama K. Harmful Effect Of Anti-Zona Pellusida Antibodies in Folliculogenesis, Oogen-esis, and Fertilization. Journal of Reproductive Immunology. 2009;79:148-55.

7. Putra A Sumarno dan Sundari S. Pertemuan Ilmiah Bidang Imuno-histokimia dan Western Blot.
Semarang. Fakultas kedokteran Universitas Sultan Agung. 2012.

8. Paixao L, Gaspa-Reis RP, Gonzalea G, Santos A, Santana AC, Santos RM, Spritzer PM, NascimentoSaba CCA. Cigarette Smoke Impair Granulosa Cells Proliferation and Oocyte Growth After Exposure Cessation in Young Swiss Mice: An Experimental Stud. J. Ovarian Rep. 2012;5(1):24.

9. Caligioni C. Assessing reproductive status/stages in mice. Curr Protoc Neurosci. 2009;41(10):1-11.

10. Naz RK and Rajesh C. Passive Immunization For Immunocontraception: Lesson Learned From Infectious Diseases, Frontiers in Bioscience. 2004;9(1):2457-65.

11. Keizer RJ, Huitema AD, Schellens JH and Beijnen JH. Clinical Pharmacokinetics of Therapeutic Monoclonal Antibodies. J. Clinical Pharmacokinetics. 2010;49(8):493-507.

12. Baratawidjaja KG dan Rengganis I. Imunologi Dasar. Edisi ke-10. Jakarta: FK Universitas Indonesia; 2013. p. 2-618.

13. Matsuda F, Naoko I, Manabe N Dan Ohkura, S. Follicular Growth and Atresia In Mammalian Ovaries: Regulation by Survival and Death of Granulosa Cells. Reproduction and Development. 2012;58(1):44-50.

14. Abbas AK and Lichtman AH. Basic Imunology. 3rd Eds. Philadelphia: WB Saunders Company; 2011. 